\title{
Grevillea obtusiflora subsp. fecunda (Proteaceae: Grevilleoideae), a new subspecies from New South Wales
}

\author{
R.O. Makinson
}

\begin{abstract}
Makinson, R.O. (Australian National Herbarium, Centre for Plant Biodiversity Research, GPO Box 1600, Canberra, ACT 2601, Australia; email: rom@anbg.gov.au) 1997. Grevillea obtusiflora subsp. fecunda (Proteaceae: Grevilleoideae), a new subspecies from New South Wales. Telopea 7(2): 143-148. Grevillea obtusiflora R. Br. sens. strict. is reviewed in the light of newly discovered populations, and a new subspecies is described as Grevillea obtusiflora subsp. fecunda Makinson, with notes on diagnosis, ecology, and conservation status.
\end{abstract}

\section{Introduction}

Grevillea obtusiflora was originally described by Robert Brown (1830: 19) from collections made by Allan Cunningham in 'brushy hills north of Bathurst' in 1822; the exact collection locality remains uncertain. The species appears not to have been collected again until 1977 when Robert Coveny of the Royal Botanic Gardens, Sydney, discovered a root-suckering and apparently quite sterile population in Clandulla State Forest, approximately $13 \mathrm{~km}$ (direct) SSW of Rylstone in the Central Tablelands botanical district of New South Wales. These and subsequent Clandulla collections correspond well with the Type material, although examination of Cunningham's journal entries and maps suggest that this is probably not the type locality.

McGillivray (1986: 11; see also McGillivray 1993: 264-266) recognised two new taxa as subspecies of G. obtusiflora; these were subsp. kedumbensis McGillivray and subsp. granulifera McGillivray. Both were re-ranked as separate species, with an additional segregate species, G. guthrieana, by Olde \& Marriott (1994a: 726-731, see also Olde \& Marriott, 1995a: 183-4, 222-3; 1995b: 59-60), rankings with which this author agrees.

In early 1995, Richard Johnstone of Mt Annan Botanic Gardens and Jane Miller of the Cumberland Bird Observers' Group, assisting with a bird survey in the Capertee Valley about $50 \mathrm{~km} \mathrm{~N}$ of Lithgow, discovered a population of an apparently new taxon. Mr Johnstone brought the material to the author's attention, and field examination was conducted in March 1995, resulting in the location of two populations of the new taxon, here described and named as Grevillea obtusiflora subsp. fecunda R. Makinson. Both of these populations, and the Clandulla subspecies, have been examined in the field by the author. Herbarium collections of G. obtusiflora have been examined at herbaria BM, CANB, K, and NSW, including types at BM and K.

Readers are referred to McGillivray (1993, loc.cit.) and Olde \& Marriott (1994a: loc. cit.; 1995a, 1995b: loc. cit.) for typification details, full descriptions, and colour illustrations of the type subspecies and of other closely related taxa. Lectotypification of the name Grevillea obtusiflora R. Br. is pending (Makinson in Flora of Australia vol.17, in prep., publ. expected late 1997). A brief comparative description and a diagnostic key to the subspecies are given below. Terminology and character-state definitions follow 
McGillivray (1993). Specimens registered and cited elsewhere as herbarium CBG are now housed at CANB.

\section{Grevillea obtusiflora subsp. fecunda R. Makinson, subsp. nov.}

Subsp. obtusiflorae similis sed planta fecunda foliis angustioribus (1.0-1.8 mm latis) valde revolutis, subtus indumento modice denso, differt.

Type: New South Wales: Central Tablelands: c. 18 km (direct) NNE of Capertee; c. $4.7 \mathrm{~km}$ along road running NE from 'Port Macquarie' property, towards NE end of ridge, c. 3300' 34"S, c. $150^{\circ} 04 ' \mathrm{E}$, R.O. Makinson 1574 \& R. Johnstone, 10 Mar 1995 (holo CANB (CBG 9502739); iso NSW).

Low spreading shrub $50-80 \mathrm{~cm}$ tall and up to $100 \mathrm{~cm}$ wide, sometimes root-suckering, procumbent when young. Branches spreading; branchlets round in cross-section with a subsericeous indumentum, often secund especially on younger plants with the leaves pointing skywards and the leaf undersurfaces facing the distal end of the branchlet. Leaves ascending to spreading, light green when young, darkening with age, subsessile or sessile, simple, very narrowly obovate to linear, (15-) 20-30 (-40) mm long, 1.0-1.2 (-1.8) mm wide; base attenuate; apex mucronate with a short blunt point $0.3-0.5 \mathrm{~mm}$ long; margin smoothly revolute, usually concealing all of the undersurface including the midvein, often a few leaves with a narrow strip of the undersurface exposed; upper surface subsericeous to subvillous on young leaves, on older leaves densely granulose (old hair bases) and often also with an open appressed indumentum persisting; lower surface (when visible) with an open appressed indumentum, the ground-tissue clearly visible between the hairs at $10 \times$ magnification; venation of the upper surface obscure; venation of the lower surface with a scarcely prominent midvein evident over the full length of the leaf. Conflorescences terminal, erect, simple, sessile or subsessile; peduncles up to $1.5 \mathrm{~mm}$ long, subsericeous to tomentose; rachises 1.5-3 mm long, tomentose; conflorescences a loose 1- or 2- $(-4)$ -flowered cluster, often with a few other buds resting at an early stage (only autumn flowering seen); bracts ovate to triangular, $0.7-0.8 \mathrm{~mm}$ long, $0.4 \mathrm{~mm}$ wide, outer surface tomentose, inner surface glabrous or with a few hairs near the apex, bracts deciduous when the buds are c. $1.5 \mathrm{~mm}$ long; floral orientation and order of opening not determined; pedicels spreading, 3-7 mm long, open-tomentose; torus oblique at c. $40^{\circ}, 1.2-1.4 \mathrm{~mm}$ across; perianth dilated at the base, c. $1.5-2 \mathrm{~mm}$ across, outer surface below the curve with an open indumentum of appressed to ascending wavy-armed hairs, apical (limb) cups tomentose, inner surface glabrous in the basal $2 \mathrm{~mm}$ then with a dense beard of retrorse ascending hairs on the ventral tepals (only) extending for $2.5 \mathrm{~mm}$, then scattered appressed hairs on both dorsal and ventral tepals to the base of the limb cups; limb depressed-globose, $1.7 \mathrm{~mm}$ long, $2.1 \mathrm{~mm}$ broad; nectary subreniform, extending $0.3-0.4 \mathrm{~mm}$ beyond the toral rim, upper surface convex, margin entire; pistil 14-18 mm long; stipe sometimes barely evident, $0-0.3 \mathrm{~mm}$ long; ovary sessile or subsessile, obliquely ellipsoid, 1.2-1.5 mm long, villous; ovule attachment not determined; style scarcely exserted from the dorsal suture of the perianth prior to release of style-end, loosely villous especially on the flanks and the dorsal side with biramous hairs, the indumentum persisting on the dorsal side right to the apex, and also with erect simple multicellular (possibly glandular) hairs c. $0.05-0.1 \mathrm{~mm}$ long in the apical $3-4 \mathrm{~mm}$ especially on the ventral side; pollenpresenter oblique at c. $75^{\circ}$, obovate to almost round, convex, $1.5-1.7 \mathrm{~mm}$ long, 1.4-2.0 mm wide, $0.3-0.3 \mathrm{~mm}$ high, stigma central to distally off-centre. Follicle erect on the pedicel, narrowly and obliquely ellipsoid or slightly ovoid, 11-13.5 mm long, 4-5 mm wide, style persistent, erect; surface faintly longitudinally ridged along the dorsal side, loosely subsericeous to loosely subvillous; pericarp $0.4 \mathrm{~mm}$ across at the suture, $0.3 \mathrm{~mm}$ thick at centre-face, $0.5 \mathrm{~mm}$ thick at the dorsal side, texture crustaceous. Seeds (Johnstone 485 - immature) obliquely ellipsoid, $9 \mathrm{~mm}$ long, c. $2.4 \mathrm{~mm}$ 
wide, margin recurved, anterior edge with a narrow waxy wing c. $0.2 \mathrm{~mm}$ wide (possibly not persistent); outer face convex with a fine downy covering of minute hairlike processes; inner face sunken, flat, appearing colliculose with the elevations shiny; apical elaiosome triangular, $1.6-1.9 \mathrm{~mm}$ long.

Flower colour: perianth usually deep pink to crimson, paling to pink or cream along the dorsal side and with a cream limb, or occasionally pale pink or cream deepening to a weak red along the dorsal side; style deep pink to red with white hairs except for a sometimes yellowish style-end.

The epithet is from the Latin: fecundus - fruitful, fertile; alluding to the copious fruiting of this subspecies in contrast to the apparently quite sterile, vegetatively reproducing type subspecies.

Diagnostic features: subsp. fecunda differs from subsp. obtusiflora in relatively minor foliar and floral characters. Subsp. obtusiflora has leaves $1.5-5 \mathrm{~mm}$ wide, with the margins only shortly recurved or shortly revolute, usually with most leaves on a plant having most of the undersurface visible; the leaf undersurface usually more or less densely subsericeous (hairs usually completely obscuring the ground tissue) or occasionally open-villous; the upper surface with the granules less prominent than in subsp. fecunda, and more rapidly glabrescent; the perianth significantly broader (2.5-3 $\mathrm{mm}$ across); the pistils longer (18-23 $\mathrm{mm}$ long); the stylar indumentum sometimes lacking minute erect multicellular hairs (e.g. Coveny 9563, Makinson 1576, both from Clandulla) but sometimes with them (Cunningham 197/1822, Brushy Hills north from Bathurst, isotype at K); the dominant stylar indumentum of biramous hairs sometimes becomes sparse or absent within 2-3 mm of the apex (e.g. Coveny 9563) or remains dense to the apex on the dorsal side (Makinson 1576). The Coveny collection is unusual in the open-villous leaf undersurface; all other plants seen of this population are subsericeous.

Distribution: restricted to an area in the New South Wales Central Tablelands in the Capertee Valley SSE of Kandos. Positions of known populations are given under 'Specimens examined' below. The new taxon is on the catchment of the east-flowing Capertee River. Subsp. obtusiflora occurs some $15 \mathrm{~km}$ away at Clandulla, and both this population, and the general type locality north of Bathurst, are on the other side of the Great Dividing Range watershed, on the catchment of the west-flowing Cudgegong and Macquarie Rivers.

Habitat \& ecology: the two populations seen are both growing in a distinctive orange loamy soil with sandstone boulders, at an elevation of about $570 \mathrm{~m}$. At the 'Port Macquarie' (ridge) site, vegetation is a relatively undisturbed low open dry sclerophyll forest with Eucalyptus tenella, E. fibrosa, E. macrorrhyncha, E. punctata, Callitris endlicheri, Leptospermum ?continentale, Monotoca elliptica, Acacia buxifolia, Indigofera sp., Persoonia linearis, and Pomax umbellata. The grevillea is confined to the upper slopes of the ridge, and shows a definite association with mechanically disturbed ground along the road. At the 'Kooringle Woolshed' site, soil type is similar and is probably part of the same formation, now dissected by the Capertee River. Native vegetation at this site is remnant dry sclerophyll forest with Eucalyptus tenella and a mixed shrubby understorey. Brief searches elsewhere in the valley failed to locate other roadside populations. It is likely that the taxon is substrate-specific, and this soil formation should outcrop elsewhere in the valley; the soil type and Eucalyptus tenella may prove to be good indicators for the grevillea.

Reproduction: subsp. fecunda does root-sucker (Makinson 1571, CANB duplicate) but also sets copious numbers of fruits. Mature seeds had all been shed at time of collection, and sifting of leaf litter did not yield any. In common with other Grevillea species with elaiosomes or waxy wings on the seeds, it is likely that mature seeds are 
rapidly gathered and dispersed by ants (cf. G. wilkinsonii, Makinson 1993: 357; G. ramosissima, W. Molyneux, pers. comm., 1993; Olde \& Marriott 1994b: 93). No seedlings were observed but it is likely that the seeds are fertile.

By contrast, subsp. obtusiflora (Clandulla population) is apparently wholly dependent on root-suckering for reproduction; suckers may arise at least five feet from a parent ramet. It is likely that the Clandulla population comprises a very few clonal lines.

Ranking: neither subspecies has been fully surveyed for variation as yet, and the character state variation noted here is based on limited samples from both taxa. From the material seen there are relatively few strongly diagnostic differences, but enough to warrant taxonomic recognition.

Naming of this taxon poses the issue of whether the rank of subspecies is taxonomically meaningful and descriptively useful. Whilst the morphological distinctions between subsp. obtusiflora and subsp. fecunda are slight, with several characters varying only in degree of expression or (perianth width, pistil length) in adjunct ranges of measurement, there is an apparent strong difference in mode of reproduction as discussed above, with subsp. obtusiflora not known to set fruit or seed. This feature, coupled with an apparent geographic disjunction of about $15 \mathrm{~km}$ (not confirmed), might reasonably be taken as grounds for assuming geographic isolation. Recent workers in Grevillea have differed on the significance of such differences, with McGillivray (1993) having a very inclusive morphologically-based implicit species concept, and others adopting a variant of the Biological Species Concept and arguing that 'isolated, self-reproducing [i.e. reproductively isolated - ROM] populations exhibiting morphological consistency ... should be regarded as species, irrespective of the kind and degree of morphological distinction' (Olde \& Marriott, 1993: 239). The latter authors, however (loc. cit.), then admit that in relation to the ranking of 'allopatric populations exhibiting only slight morphological discontinuity ... we would acknowledge the value of the rank of subspecies or variety or a mixture of the two'.

There are numerous examples in Grevillea of species with (usually geographically peripheral) local populations exhibiting a partial or total 'abandonment' of sexual reproduction correlated with minor morphological differences (e.g. populations of G. arenaria subsp. canescens (R. Br.) Olde \& Marriott in the area of Gilgandra, N.S.W.; G. masonii Olde \& Marriott, a very narrow segregate from G. banyabba Olde \& Marriott; various localised populations in G. lavandulacea Schlechtd. and G. lanigera A. Cunn. ex $\mathrm{R}$. Br., to name a few). In most of these cases there is some variably expressed capacity for vegetative reproduction in the more widespread, presumed 'parental' populations. Breeding systems for these, and most other, Grevillea species have not yet been examined, but it is quite possible that an inability to set fruit in local (possibly clonal) populations may result from self-incompatibility or compounded inbreeding depression within such populations of what may be preferentially out-breeding species. To what extent such features may become genetically fixed and irreversible has not been studied for any cases in Grevillea of which I am aware. Given the absence of data, assumptions of reproductive isolation and/or reproductive incompatibility between taxa should be made with care. This is not to imply that the two subspecies of G. obtusiflora are not reproductively isolated, but rather that the capacity to lose or suppress a capability for sexual reproduction may be a reasonably common and plastic feature within lineages classified at species rank, and should not therefore be taken as an absolute determinant of rank, at least where other characters indicate a very close relationship.

It seems likely that G. obtusiflora subsp. obtusiflora is such a geographical (and possibly recent) isolate from an ancestral population that resembled subsp. fecunda at least in its 
capacity for sexual reproduction. It is not out of the question that the type population of subsp. obtusiflora (almost certainly not the Clandulla population) may, if rediscovered, prove to be fertile, but there is no indication of this from the type specimens or in the protologue. In this event, the consistent foliar and floral differences noted here would still warrant the maintenance of two subspecies.

In the circumstances, a rank of subspecies seems justified in respect of both likely degree of lineage divergence and in the inetrests of maximising the information content of the formal nomenclature.

\section{Key to the subspecies}

1 Leaves 1.5-5 mm wide, margins shortly recurved or revolute leaving most of the undersurface exposed; leaf undersurface densely subsericeous (ground-tissue not visible between hairs), or occasionally open-villous; perianth $2.5-3 \mathrm{~mm}$ across .......... subsp. obtusiflora

1* Leaves 1.0-1.2 (-1.8) mm wide, margins strongly revolute, completely enclosing the undersurface on most leaves; leaf undersurface, when visible, with an open appressed indumentum (ground-tissue clearly visible between the hairs at $10 \times$ maginification); perianth $1.5-2 \mathrm{~mm}$ across subsp. fecunda

Affinities: Grevillea obtusiflora belongs to the Section Ptychocarpa sensu Bentham (1870: 420). Closely related taxa include G. kedumbensis (McGillivray) Olde \& Marriott, G. granulifera (McGillivray) Olde \& Marriott, G. guthrieana Olde \& Marriott, and G. mucronulata $\mathrm{R}$. Br. These species generally have leaves more than $2 \mathrm{~mm}$ wide (and usually more than $5 \mathrm{~mm}$ wide), and the perianth predominantly green or cream in colour. The forthcoming treatment in Flora of Australia vol. 17 (Makinson, in prep., expected publ. late 1997), will provide fuller comparative notes and diagnostic keys.

Conservation status: one of the known populations of subsp. fecunda (represented by Johnstone 485) is on a rocky ridge, unsuitable for cropping or grazing; the tenure of the site is not known, but the population is probably relatively secure. The other population (e.g. Makinson 1575) is in remnant vegetation on a roadside easement and is not secure. A conservation coding of $2 \mathrm{Vi}$ (following the criteria and coding of Briggs \& Leigh, 1996) is recommended pending full survey, where (2) indicates a range of less than $100 \mathrm{~km},(\mathrm{~V})$ indicates taxon vulnerable, not presently endangered but at risk over 20-50 years, and (i) indicates taxon inadequately reserved.

Specimens examined: New South Wales: Central Tablelands: $6.7 \mathrm{~km}$ along road towards 'Port Macquarie' property from Glen Alice-Rylstone Road, 330' 40"S, $150^{\circ} 03^{\prime} 30^{\prime \prime} E$, R. Johnstone 485, J. Miller $\mathcal{E}$ T. Wilson, $19 \mathrm{Feb} 1995$ (NSW); c. $17 \mathrm{~km}$ (direct) NNE of Capertee, $4 \mathrm{~km}$ along road running NE from 'Port Macquarie' property, 3300' 36" S, 15003' 46" E, R. Makinson 1571 \& R. Johnstone, 10 Mar 1995 (CBG 9502738 at CANB, MEL, NSW); c. 14 km SSE of Kandos, 2.2 km from Rylstone to Glen Alice road S along road from 'Kooringle' Woolshed, 32 $58^{\prime}$ S, 150 $03^{\prime}$ 30" E, R. Makinson 1575 \& R. Johnstone, 10 Mar 1995 (CBG 9502742 at CANB).

\section{Acknowledgments}

Thanks to Richard Johnstone, co-discoverer of the new subspecies, for assistance with fieldwork; to Richard Johnstone, Helen Hewson (CANB) and Lyn Craven (CANB) for helpful comments on the manuscript; to the Curators of herbaria BM, K, MEL, and NSW for access to their collections, and to Peter Wilson for assistance with the Latin diagnosis. This paper was prepared, and types examined, while the author was Australian Botanical Liaison Officer at the Royal Botanic Gardens, Kew, UK, 
supported by funding from the Australian Biological Resources Study and the Australian National Herbarium; I am grateful to those organisations for their financial support for the posting.

\section{References}

Bentham, G. (1870) Flora Australiensis, vol. 5. (Reeve \& Co. : London).

Brown, R. (1830) Supplementum Primum Prodromi Florae Novae Hollandiae: ... Proteaceas Novas (R. Taylor: London).

Briggs, J.D. \& J. Leigh (1996) Rare or Threatened Australian Plants, revised edition. (CSIRO Publishing: Collingwood).

McGillivray, D.J. (1986) New names in Grevillea (Proteaceae). (The author: Castle Hill). [Facsimile in McGillivray, 1993, appendix II].

McGillivray, D.J. (1993) Grevillea (Proteaceae) - a taxonomic revision. (Melbourne University Press: Melbourne).

Makinson, R.O. (1993) Grevillea wilkinsonii (Proteaceae) a new species from southern New South Wales. Telopea 5(2): 351-358.

Olde, P.M. \& Marriott, N.R. (1993) New species and taxonomic changes in Grevillea (Proteaceae) from south-west Western Australia. Nuytsia 9(2): 237-304.

Olde, P.M. \& Marriott, N. (1994a) A taxonomic revision of Grevillea arenaria and Grevillea obtusiflora (Proteaceae: Grevilleoideae). Telopea 5(4): 711-733.

Olde, P.M. \& N. Marriott. (1994b) The Grevillea Book, vol. 1. (Kangaroo Press: Kenthurst).

Olde, P.M. \& N. Marriott. (1995a) The Grevillea Book, vol. 2. (Kangaroo Press: Kenthurst).

Olde, P.M. \& N. Marriott. (1995b) The Grevillea Book, vol. 3. (Kangaroo Press: Kenthurst). 